\title{
CAMPAIGN AGONES: \\ TOWARDS A CLASSIFICATION OF GREEK ATHLETIC COMPETITIONS
}

\author{
By Christian Mann
}

Summary: At several occasions during his campaigns, Alexander the Great staged gymnic, hippic and musical competitions. Until now scholars have assumed that the king founded new festivals, but the ancient evidence makes it quite clear that it were singular, non-recurrent events. Competitions like that, for which I suggest the term "campaign agones", are also known from other Greek armies. "Campaign agones" should be added to the well-known categories (competitions at recurrent festivals, funeral contests, gymnasium agones) as a distinct, although less important, category in the Greek agonistic world.

When it comes to the classification of ancient athletic competitions, historians have devoted nearly all their attention to the differences between "crown contests" (agones stephanitai) and "prize contests" (agones thematikoi). There are different opinions how these terms should be understood and whether they provide us with historically useful analytical categories. ${ }^{1}$ However, both expressions refer to a type of competition that was held in a certain location and within a fixed cycle of one, two, or four years. These competitions typically involved predetermined disciplines and age groups and were dedicated to particular deities, for example Zeus Olympios, Apollon Pythios, or to deified kings. They bore

* I am indebted to Thomas Heine Nielsen and Sebastian Scharff for corrections and remarks to an earlier draft of this article. The article has also profited from the anonymous reviewer's comments.

1 Fundamental work on this subject was done by Harry Pleket (1975: 56-71; 2004: 8083). For the status quaestionis see Parker 2004; Remijsen 2011; Slater 2013. 
names derived from the deity in question, like Olympia, Pythia, or from monarchs such as Basileia. These cyclic agones were doubtlessly the most important and prestigious events in ancient Greek sport - which explains why research has so far been concerned mostly with them. However, there were other types of athletic competition that merit attention.

In a recent study, Thomas Heine Nielsen presented a catalogue of athletic competitions in Archaic and Classical Greece, laying a new foundation for further investigation. ${ }^{2}$ Nielsen demonstrates conclusively that even before the celebrated "explosion agonistique" ${ }^{3}$ in the Hellenistic and the Roman Imperial Era, the number of agones was very high. Nielsen differentiates between "competitions at recurrent religious festivals" (chapter 1.3.1), i.e. the cyclic agones mentioned above, and "funeral contests" (chapter 1.2), which are prominent in Homer and attested also in Archaic inscriptions as a rather common element of aristocratic funerary practices. During the Classical period, funeral games fell into disuse but were still held at some occasions, e.g. in 374/3 B.C. for King Euagoras of Salamis in Cyprus. ${ }^{4}$ Because of Nielsen's focus on the earlier periods of Greek history, he makes no mention of the contests in gymnasia, which were important during the Hellenistic and the Roman Imperial Era.

But there is another kind of athletic contests, mentioned by Nielsen only in passing: Non-cyclic competitions that took place at one single occasion, but not as part of a funeral reception: “... contests which were staged only once, to mark victory in war, the burial of a great man, or some other important event". Nielsen refers to the competitions staged by the "Ten Thousand" after reaching the Black Sea and to five sets of agones during the campaigns of Alexander the Great. It is this type of athletic contests, rarely mentioned in publications on ancient sport, that will be discussed in this article, the goal being to analyze its defining characteristics and to establish it as a new category of Greek athletics. I want to suggest the term "campaign agones" to identify this category.

2 Nielsen 2018a; cf. id. 2016.

3 Robert 1984: 38.

4 Isoc. Euagoras 1. Roller 1981a is fundamental on athletic funeral games, providing an overview of the literary and epigraphic sources. For funeral games on black-figure ceramic see Roller 1981b.

5 Nielsen 2018a: 28. 
The most detailed description of a campaign agon in Greek literature is a passage in Xenophon's Anabasis. Early in 400 B.C., when the Greek army reaches Trapezus on the Black Sea and the end of danger and all their troubles seems near, the men celebrate this fortunate turn of events. They offer sacrifices to Zeus Soter, Heracles, and other divinities; afterwards, they elect the Spartan Dracontius to be the leader of the upcoming competitions:

[26] When, accordingly, the sacrifice had been completed, they turned over the hides to Dracontius and bade him lead the way to the place he had fixed upon for his race-course. He pointed out the precise spot where they chanced to be standing, and said, "This hill is superb for running, wherever you please." "How, then," they said, "can men wrestle on ground so hard and overgrown as this is?" And he replied, "The one that is thrown will get hurt a bit more." [27] The events were, a stadium race for boys, most of them belonging to the captives, a long race, in which more than sixty Cretans took part, wrestling, boxing, and the pancratium ...; and it made a fine spectacle; for there were a great many entries and, inasmuch as the comrades of the contestants were looking on, there was a great deal of rivalry. [28] There were horseraces also, and the riders had to drive their horses down the steep slope, turn them around on the shore, and bring them back again to the altar. And on the way down most of the horses rolled over and over, while on the way up, against the exceedingly steep incline, they found it hard to keep on at a walk; so there was much shouting and laughter and cheering. ${ }^{6}$

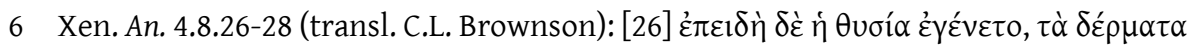

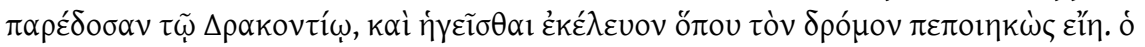

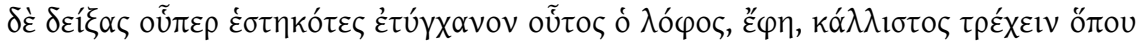

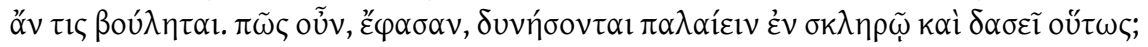

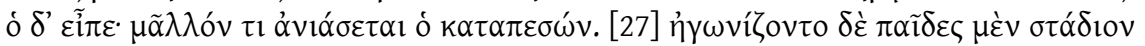

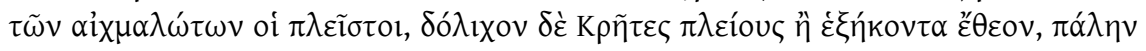

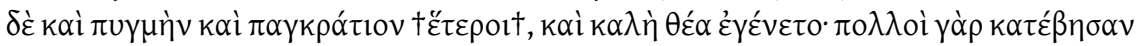

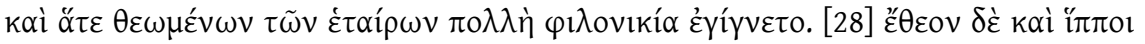

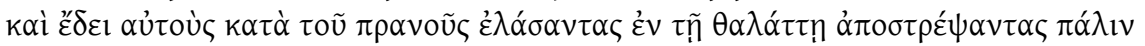

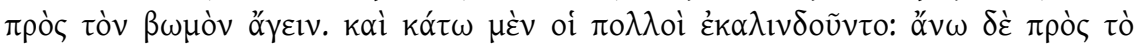


Here we find some of the events familiar from Olympia and other big festivals: foot races, wrestling, boxing, pancratium, and horse races. There were no chariot races, which is hardly surprising, but other disciplines too, such as the diaulos and the hoplites, the jump, the discus throw, and the javelin throw, are absent as well unless they were mentioned in the lacuna after the pancratium. ${ }^{7}$ Naturally, the soldiers did not have access to a stadium or a hippodrome, and Xenophon makes a point of emphasizing the challenges posed by their improvised sports venues. As far as the competitors are concerned, he explicitly states that the stadium race among boys was mostly, but not exclusively, undertaken by prisoners of war. In the other disciplines it was the soldiers themselves who competed. The Cretans among them dominated the long-distance run since this discipline was very popular on their island. ${ }^{8}$ The audience was the army, including perhaps the female camp-followers, if we follow the emendation of $\tau \tilde{\omega} v \dot{\varepsilon} \tau \alpha i ́ \rho \omega v$ to $\tau \tilde{\omega} v \dot{\varepsilon} \tau \alpha 1 \rho \tilde{\omega} v .{ }^{9}$ We can probably concur that the hides of the sacrificed animals were offered as prizes since there can hardly be any other explanation of why these were handed over to Dracontius. Furthermore, there are other attestations of hides being used in this manner; Homer already mentions them as common prizes for runners. ${ }^{10}$

Xenophon chronicles two other agones in his Anabasis, though very briefly. In March of 401 B.C., ${ }^{11}$ when the army camped at Peltae, sacrifices were offered according to the Arcadian Lycaea and under the direction

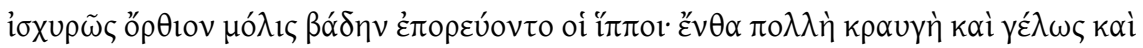

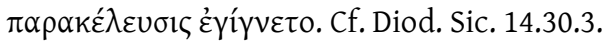

For this agon, see Golden 1998: 1-5 (cf. Golden 1997: 327-31); Nielsen 2007: 16; Kyle 2016: 224.

7 A lack of diskoi and halteres might have prevented two of the disciplines, but we know that officers of Alexander's army had athletic equipment carried during the campaigns (Ath. 12.539c; Plut. Alex. 40.1).

8 Nielsen 2018a: 81-82, with references. The famous Ergoteles of Himera, Olympic victor in 472 and 464 B.C., was a citizen of Cnossus before he moved to Sicily.

9 Golden 1998: 5.

10 Hom. Il. 22.159-61.

11 Dated according to the chart in Lee 2007: table 1. 
of the Arcadian Xenias, followed by an athletic contest with golden strigils as prizes. Xenophon explicitly states that Cyrus himself was among the spectators, so the Persian prince attended his mercenaries' typically Greek spectacle. ${ }^{12}$ This agon was inspired by a festival held back in Greece, but it was not intended as precise imitation. For example, during the Arcadian Lycaea, the winners were offered bronze shields and not golden strigils. ${ }^{13}$ The third agon in Xenophon's Anabasis took place in March 400 B.C. when the Greek soldiers held processions and gymnic contests at Cotyora, separated according to their ethnic origins. ${ }^{14}$

By far the largest number of campaign agones attested in the ancient sources refers to another famous anabasis, that of Alexander the Great and his army. Arrian mentions 16 sets of competitions from the passage over the Hellespont in 334 B.C. to Alexander's death in Babylon in 323 B.C. For most of them, Arrian is the only source, but some are referred to by other authors:

- 333 B.C. at Soli/Cilicia: gymnic and musical contests (Arr. Anab. 2.5.8; Curt. 3.7.3f.)

- 332 B.C. at Tyre: gymnic contests (Arr. Anab. 2.24.6)

- 332 B.C. at Memphis: gymnic and musical contests (Arr. Anab. 3.1.4)

- 331 B.C. at Memphis: gymnic and musical contests (Arr. Anab. 3.5.2)

- 331 B.C. at Tyre: gymnic and musical contests (Arr. Anab. 3.6.1; Plut. Alex. 29)

- 331 B.C. at Susa: gymnic contests (Arr. Anab. 3.16.9)

- 330 B.C.: at Zadracarta/Hyrcania: gymnic contests (Arr. Anab. 3.25.1)

- 329 B.C. at Alexandria Eschate: gymnic and hippic contests (Arr. Anab. 4.4.1)

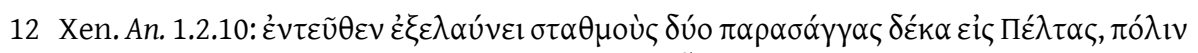

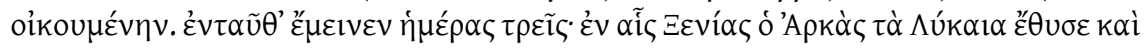

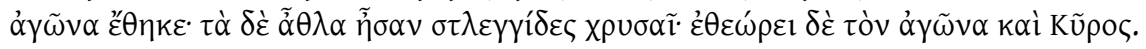
For Cyrus' eventual motives, see Nielsen 2015: 251-52.

13 Pind. Nem. 10.45-48; cf. Ringwood 1927: 97; Nielsen 2018b: 412.

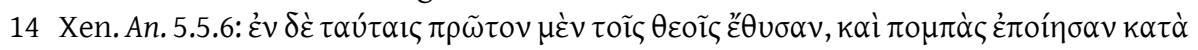

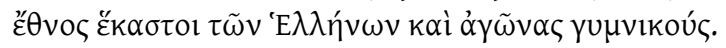


- 327 B.C. at the Indus River: gymnic and hippic contests (Arr. Anab. 5.3.5f.)

- 326 B.C. at Taxila: gymnic and hippic contests (Arr. Anab. 5.8.3)

- 326 B.C. at the Hydaspes River: gymnic and hippic contests (Arr. Anab. 5.20.1)

- 326 B.C. at the Hyphasis River: gymnic and hippic contests (Arr. Anab. 5.29.1f.)

- 325 B.C. at the Indus River, before the departure of Nearchus' fleet: gymnic contests, organized by Nearchus (Arr. Ind. 21.2)

- 325/4 B.C. in Carmania: gymnic and musical contests (Arr. Anab. 6.28.3; Arr. Ind. 36.3; Diod. Sic. 17.106.4f.)

- 324 B.C. at Ecbatana: gymnic and musical contests, drinking contest (Arr. Anab. 7.14.1; Plut. Alex. 72.1; Diod. Sic. 17.110.7f.)

- 323 B.C. at Babylon: gymnic and musical contests (Arr. Anab. 7.14.8-10)

- 323 B.C. at Babylon: naval contest (Arr. Anab. 7.23.5)

The attribution of sources to events is not entirely clear in all cases, and there is a debate whether the two agones at Memphis might have been a single one, and so other historians reach slightly different numbers. ${ }^{15}$ However, the overall result, i.e. the very high number of agonistic events during the campaigns of Alexander the Great, remains the same. A crucial element of these competitions is their non-recurrent character. It is important to emphasize the fact that they were not intended as foundations of new festivals since they have often been misinterpreted as such - even by experts of ancient sport like Louis Robert and Luigi Moretti. According to Robert, Alexander founded the Basileia in Egypt, Moretti

15 Will 1986: 82-83; Oliva 1993: 95-96; Miller 2004: 196-97; Adams 2007: 130-38; Di Nanni Durante 2015: 17-20; Lehmann 2015: 208-13. So far, there is no debate on Alexander's agones since the studies mentioned here ignore the results obtained by the other authors.

The agon that Alexander is said to have organized to honor the Indian sage Calanus is unanimously excluded from the list, since its historicity seems fairly questionable: The competition is mentioned only by Athenaeus $(10,437 \mathrm{a})$ and Claudius Aelianus (VH 2.41), but not by Arrian, despite the fact that he describes the death of Calanus in great detail (Anab. 7.3; cf. 7.18.1). In addition, it would have been the only agon that included musical disciplines during Alexander's campaign east of the Persian heartland. 
says the same for the Asclepieia at Soli and the Heracleia at Tyre; building on these statements, Di Nanni Durante recently asserted that Alexander instituted new agones from Asia Minor to India. ${ }^{16}$ Without a category like campaign agones in mind, such a misinterpretation is hardly surprising. However, the ancient sources do not support this point of view. Quite the contrary, in fact: with regard to the agon in Soli, for example, Arrian states that Alexander - after recovering from a serious illness - offered sacrifices to Asclepius and held competitions. ${ }^{17}$ This is something entirely different from the foundation of a new festival called Asclepieia. Similar phrasing is used to describe the first agon at Tyre when Alexander sacrificed to Heracles/Melqart and held gymnic contests as well as a torch relay. ${ }^{18}$ Nothing points to continuity with the penteteric Heracleia mentioned in 2 Maccabees; as was the case with the Egyptian Basileia, the festival is most likely a Hellenistic creation. ${ }^{19}$ Founding agones was not uncommon to Greek monarchs and tyrants before Alexander, even in the house of the Argeads: King Archelaus had instituted an agon at Dium that Philipp II and Alexander himself held as well. ${ }^{20}$ And in the Hellenistic period, the establishment of agonistic festivals was a popular method of rulers' self-presentation; ${ }^{21}$ however, no initiatives of this kind can be traced back to Alexander. ${ }^{22}$

16 Robert 1933: 136; Moretti 1975: 106; Di Nanni Durante 2015: 11.

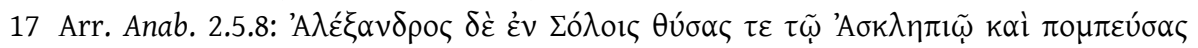

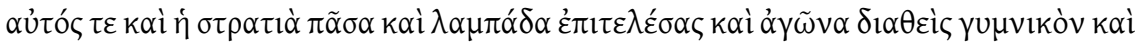

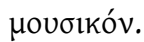

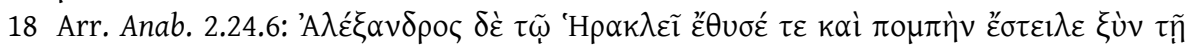

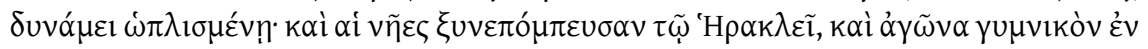

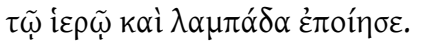

192 Macc. 4.18-20; in the commentaries on this passage, we consistently find the postulate of continuity (e.g. Schwartz 2008: 226-27).

20 Diod. Sic. 17.16.3; Arr. Anab. 1.11.1.

21 See Mann 2018a: 466-73, with further bibliography.

22 By choosing to neither establish agones nor take part in horse and chariot races himself, Alexander deviates from the usual behavior of Greek monarchs; see Mann forthcoming. 
Another argument for the non-recurrent, situational nature of Alexander's agonistic events is the victory of a Macedonian who competed successfully during the first agon at Tyre: ${ }^{23}$

When Alexander conquered with the spear the island-city of Tyre and exalted Heracles with prize-bringing competitions, Antigonus, son of Callas, was the first of the hetairoi to win double wreaths for the hoplite and the stadium race.

This inscription, the only epigraphic testimony for the competitions during Alexander's campaigns, provides us with important information on the participants and disciplines. Antigonus was the champion of not one but two disciplines, which were also part of the standard program of the Olympic Games and numerous other agones. Obviously he considered his agonistic triumph at Tyre a major achievement so he spent money on a poet and a monument to have it remembered after his return to Macedonia. The main goal of the poem is to present Antigonus as the first (of all the hetairoi) who won two victories in Alexander's campaign agones. ${ }^{24}$ The contest itself is connected to the situation, the conquest of Tyre; although ivíka makes it clear that some time had passed between the contest and the erection of the monument, there is no hint in the epigram that points at a recurrent festival.

It stands to reason that we can generalize and assume that the gymnic contests held during Alexander's campaigns included the usual combat sports and races, analogous to the competition of Greek soldiers mentioned in Xenophon's Anabasis. As far as the hippic contests are concerned, we can expect them to have been horse races, not chariot races, since the latter require much more elaborate preparations: suitable terrain, chariots, and trained charioteers are essential and it is unclear how

23 This is an inscription on the base of a statue in Amphipolis (C. Koukouli-Chrysanthaki, AD 26 Mel. (1971) [1973] 120-27; Moretti 1975: no. 113; SEG XXXXVIII 716bis):

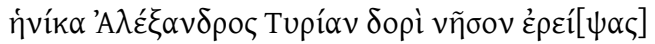

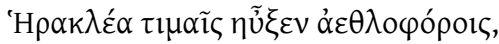

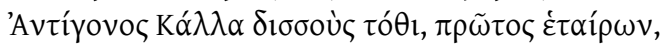

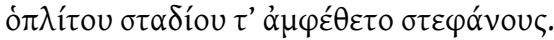

24 Being the "first" (woman, Ionian etc.) is a common motif in agonistic epigrams, see the examples collected in Ebert 1972. 
these could have been provided at the spur of a moment. ${ }^{25}$ During the second competitions at Tyre, dithyramb and tragedy are verified as musical disciplines. ${ }^{26}$ The sources even name famous actors who arrived from Greece, specifically to take part in the competitions. The same is reported for the first agon at Memphis and the agon at Ecbatana; for the latter, the number of actors who showed up is specified as 3,000. ${ }^{27}$ The literary sources offer no information on the participants who competed in the gymnic and hippic competitions but we can safely assume that it was the soldiers themselves who competed here. The inscription found in Amphipolis proves that even high-ranking Macedonians were involved since, even though this Antigonus is not mentioned anywhere else, he doubtlessly was one of the hetairoi and was able to afford a victory monument after returning to Macedonia. According to Arrian, a gymnic agon for boys was held in 324 B.C. in Ecbatana; ${ }^{28}$ as was the case in Trapezus, its participants may partly have been prisoners of war.

Apart from the two most famous anabaseis there is only sporadic evidence of campaign agones. According to Herodotus, Xerxes, who had previously already held a naval competition, ${ }^{29}$ after arriving in Thessaly organized a horse race in which the Persian riders competed with their Thessalian allies. Even though the latter were considered the best horse breeders in all of Greece, they fell far behind the Persians..$^{30}$ Thucydides chronicles a competition that never took place but that can indicate an established practice: when, in the winter of 418/7 B.C., the Argives had joined forces with the Spartans, they urged Athens to retreat from the fortress built close to Epidaurus. The Athenians sent Demosthenes to bring home the troops. However, he had different plans and cunningly

25 Günther 2013: 296 assumes chariot races while providing neither proof nor arguments.

26 Plut. Alex. 29.

27 Arr. Anab. 3.1.4 (Memphis); Arr. Anab. 7.14.8-10; Plut. Alex. 72.1 (Ecbatana). Here, Plutarch obviously confused the agon during which Hephaistion died with the funeral games held in his honor.

28 Arr. Anab. 7.14.1.

29 Hdt. 7.44.

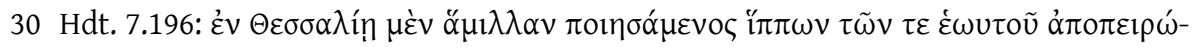

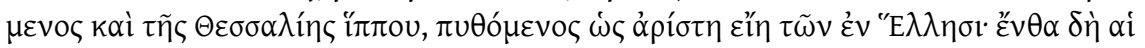

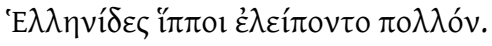


used a ruse: seeing that the Athenians were a minority among the garrison's soldiers and knowing they would surely be defeated in case of a conflict, he lured the soldiers out of the fortress under the pretense of organizing a gymnic agon. Afterwards, he locked the gates and let no-one back in except the Athenians. ${ }^{31}$ Thucydides also details that during their departure for the fatal Sicilian expedition in 415 B.C., the ships raced to the island Aegina. ${ }^{32}$ In both cases, the agones are mentioned only in passing, which actually is an important point: Thucydides apparently felt no need to explain to his readers why a ruse that included a competition was successful in the first case and why the Athenian fleet held a rowing race at the start of such an important campaign.

In the Hellenistic period, quite surprisingly, sources for campaign agones are scarce, ${ }^{33}$ but there is one important passage explaining the commander's motivation: in 226 B.C., the Spartan king Cleomenes invaded the territory of Megalopolis and ravaged the land. Moreover, in a hastily constructed theater, he organized musical competitions, forcefully recruiting a group of actors that had just happened to pass by and offering a prize of 40 minae. Plutarch clarifies that it wasn't Cleomenes' need for entertainment that made him stage this performance; instead, he wanted to demean his enemies and show the world that he had everything under control. ${ }^{34}$ Therefore, organizing an agon in enemy territory seems to have been a demonstration of power.

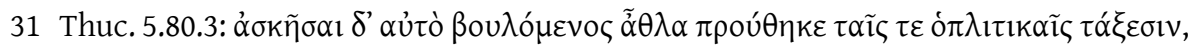

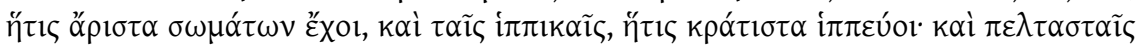

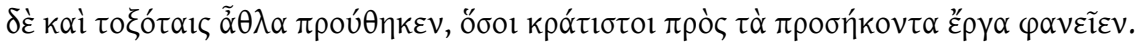
Cf. Hornblower 2008: 206: "the trick depends on Greek inability to resist watching an athletic tournament."

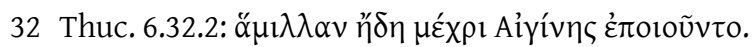

33 A TLG search has not led to any results for Polybius and other Hellenistic historians, but there might be references beyond the agonistic keywords.

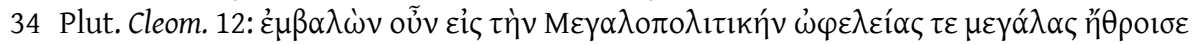

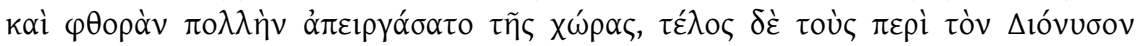

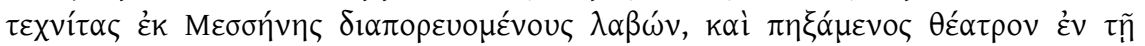

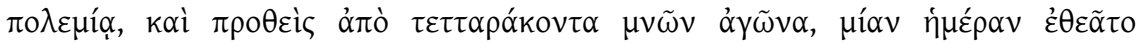

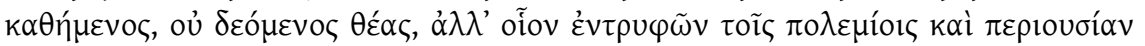

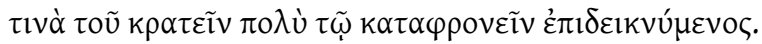


Let us now recapitulate the characteristics of campaign agones: they took place on provisionally prepared grounds that served as a substitute for stadiums, theaters, and hippodromes. The gymnic, hippic, and musical disciplines of the campaign agones are those found on the programs of recurrent festivals celebrated in Greek sanctuaries, but their number was reduced, as armies usually did not enact the full catalogue of disciplines and the competitions did not consistently include multiple age groups. However, if a fleet was present, rowing regattas could be added to the program. ${ }^{35}$ Victors were rewarded with material prizes such as strigils and hides or with monetary prizes. We cannot rule out prize wreaths, but they are not conclusively documented since the reference to a winner's wreath in the epigram of Antigonus, son of Callas, may also have been meant as a metaphor. As for the participants, we have to differentiate between the various disciplines: the soldiers usually competed in the gymnic and hippic contests; prisoners of war also competed, especially during the boys' competitions. On the other hand, the musical performances were delivered by professionals who were either specifically recruited for the occasion or who permanently accompanied the army.

Determining the functions of such campaign agones is made difficult by the fact that only few explicit statements concerning them can be found in the sources. The connection to the gods was important, but, as sacrifices and prayers do not need competitions, Greek religion cannot explain the campaign agones. First, we need to differentiate between horse and boat races on the one side and musical and gymnic disciplines on the other. The former can be seen as training for the subsequent battles since the velocity of triremes and cavalry were crucial to military success. It therefore makes sense from a functional point of view to test and improve the troops' performance. An entirely different case must be made for musical disciplines, which bring no military advantage ${ }^{36}$ and the gymnic disciplines, which are only loosely connected to battle scenarios. A good soldier, like a good athlete, did indeed have to be in excellent physical shape; however, Greek individual sports were rather ill

35 Regattas were also added to the agonistic disciplines during the funeral games for Euagoras (Isoc. Euagoras 1).

36 The aulos was important for the hoplite phalanx (e.g. Thuc. 5.70), but the musical competitions were not connected to this military function. 
suited as a preparation for battle. ${ }^{37}$ Drilling exercises that improved coordination between several troop contingencies, as the Spartan King Agesilaus organized in 395 B.C. at Ephesus, for example, are more efficient by far. After assembling his army for the subsequent Persian campaign, Agesilaus offered prizes to the best units of the individual troop categories while refraining from organizing individual sports competitions. $^{38}$

As for the function of the musical and gymnic competitions during campaigns, scholars have developed some hypotheses regarding Alexander's agones. This focus is understandable, since the comparatively high number of competitions connected to Alexander's campaigns suggests that they were of particular importance to this king and his army. Some scholars assume that they provided relaxation for the soldiers, ${ }^{39}$ others suppose that they were intended to introduce the Oriental 'barbarians' to Greek culture. ${ }^{40}$ The first idea could certainly hold true in some cases; however, it offers no definitive explanation, since soldiers could have also relaxed on rest days without these competitions. On the other hand, the second theory cannot explain the many competitions that took place far from any major settlement. If we look for characteristics that all campaign agones have in common, we first have to dismiss the idea that campaign agones developed as victory celebrations. It is true that Alexander staged gymnic and hippic competitions after the battle at the Hydaspes River, but there were no such events following the big battles of the Granicus River, Issus, or Gaugamela. Therefore, Bosworth's rather curt comment "Alexander's usual reaction to happy events" ${ }^{41}$ has to be refined. If we do try to find a common denominator, we must conclude that campaign agones mostly took place before or after important stages of the campaign: before the Athenian fleet set sail for Sicily, before Alexander and his army left the Mediterranean coast to set out for the Persian

37 On the complex relation between war and sports in ancient Greece, see the detailed discussion provided by Angeli Bernardini 2016.

38 Xen. Hell. 3.4.16-19.

39 Weiler 1975: 275; Adams 2007: 131.

40 Oliva 1993: 101; Di Nanni Durante 2015: 11.

41 Bosworth 1995: 27. 
heartland, and before he crossed the Indus River, after the Greek mercenaries had reached the Black Sea, after Alexander had recovered from a serious illness, and after his army had crossed the Gedrosian desert.

So it seems that one motif was to accentuate certain stages of the campaign by holding competitions with special reference to the king, since any campaign agon would be explicitly traced back to the king if he was the leader of the army, be it Alexander or Cleomenes. Another purpose of these agones was to strengthen the army's coherence. During any competition, the soldiers, despite the competitive nature of the event, felt like a community - more so with sports competitions than with musical disciplines. Xenophon's report of the interaction between participants and audience highlights this explicitly. ${ }^{42}$ Another motive may have been that organizing an agon was to symbolically take possession of the place in which it was held. This could have been one of the reasons behind Alexander's competitions at Memphis, since Egypt was conquered without a fight, which meant that that the Egyptians had never gotten to see the full power of the Macedonian army. As for Cleomenes' spectacle, we are explicitly told that his motive was to assert his dominance over Megalopolis, a polis that had been a thorn in the Spartans' side ever since its foundation.

As is clear, the competitions discussed here show some major differences: there is a variety of disciplines and a variety of functions. Nevertheless, there are enough common features to assign them an agonistic category of their own. Most of the evidence concerning the campaign agones refers to Alexander the Great, and it needs an explanation why this kind of competition was so important for him. ${ }^{43}$ On the other hand side, there is also evidence for campaign agones before and after Alexander, and other scholars might find more examples in the sources once the new category is established.

I will conclude with a brief look on the spectrum of Greek agones. Building on the definition of campaign agones suggested here, I classify the Greek athletic competitions as follows:

42 Xen. An. 4.8.27f.

43 See Mann forthcoming. 
1. Competitions at recurrent religious festivals, in Nielsen's terminology (2018a), were by far the most important group. A specific characteristic is their cyclic repetition. It would be misleading to call them "religious competitions" because, even though they were always combined with ritual acts like sacrifices and processions, this was not a unique characteristic: funeral games and campaign agones, too, were always accompanied by ritual acts. ${ }^{44}$ The feature that sets this group apart from all others is its connection to a sacred place: be it a big Panhellenic sanctuary for an Olympian deity or a heroon for an oikistes, for example for Miltiades the Elder on the Thracian Chersonese or for Brasidas in Amphipolis. ${ }^{45}$ Even just the statue of a heroized man, located in a gymnasium, sufficed as a cultic location, as the example of Aigiale on Amorgos shows: here, a father organized a sacrificial celebration with processions and gymnic competitions for his deceased son. ${ }^{46}$ Equally diverse were the prizes ${ }^{47}$ and the disciplines included, and diverse were the competitions' prestige in the Greek world and, of course, the social and regional origins of the participants. But nevertheless they share common features, recurrent competitions of this kind took place from the Archaic period until late Antiquity.

2. Funeral contests were, per definitionem, connected to a burial. However, the competitions did not necessarily take place immediately after the person's death; instead, they could be announced far and wide so that athletes from other poleis and regions had a chance to attend as well ${ }^{48}$ and thus make the event more prestigious. Contrary to cyclic agones held in honor of the dead, funeral games did not require the heroization of the deceased. This type of competitions might have been the earliest one, from which other agones

44 The question of whether the ritualistic context had any influence on the athletic performance has so far sparked various research positions but no debate (see Mann 2017: 429-34, with bibliography).

45 Hdt. 6.38; Thuc. 5.11.

46 IG XII(7), 515 (= Laum 1964: no. 50); for a discussion and interpretation of the long inscription, see Helmis 2003; Ekroth 2017: 391-92.

47 Overviews by Papakonstantinou 2002; Mann 2018b.

48 On the regions the participants of funeral games came from, see the collection of sources by Roller 1981a: 1-5. 
developed; at any rate, ancient sources attribute such an origin to many recurrent agones. For example, the Nemean and Isthmian games were said to have had their roots in the burials for Opheltes and Melicertes.

3. Gymnasium agones: This category can already be found in Klee's study of 1918, who lists the Theseia, the Herakleia of Chalkis and an agon in Chios. ${ }^{49}$ Their defining features are special disciplines like euexia, philoponia, and eutaxia, ${ }^{50}$ the combination of athletic disciplines with artistic skills like reading ${ }^{51}$ or with military disciplines like using a catapult or a slingshot, and the restriction of participation to certain age groups of young polis citizens..$^{52}$ Gymnasium agones could either be held as part of an annual festival for the gods like the Hermaia in the gymnasium of Beroia, ${ }^{53}$ which makes them resemble cyclic agones (category 1), or they could take place without explicit reference to a deity. For instance, the same gymnasiarchical decree from Beroia does not only mention the Hermaia, but also that the paides were supposed to demonstrate their prowess thrice a year, the winners being honored with wreaths. ${ }^{54}$ An honorary decree from Sestos praises the gymnasiarch Menas for having organized monthly competitions in gymnasia and for therefore having led the youth of the polis to andreia and philoponia; the disciplines mentioned are javelin throwing, archery, and foot races. ${ }^{55}$ Gymnasium agones are on record from the 4th century B.C., reaching their peak during the Hellenistic and the Roman Imperial Era.

49 Klee 1918: 42-45.

50 See Crowther 1991; Gauthier \& Hatzopoulos 1993: 102-5.

51 Syll. $^{3} 959$ (Chios, $3 \mathrm{rd} / 2$ nd cent. B.C.).

52 Syll. $^{3} 1061$ (Samos, 2nd cent. B.C.). On military exercises in Hellenistic gymnasia, see Chankowski 2004; Kah 2004.

53 EKM 1. Beroia 1, 1l. B 45-71.

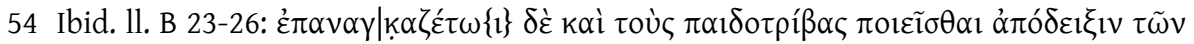

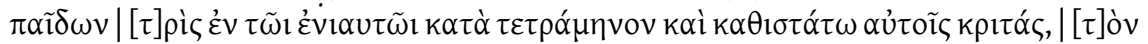

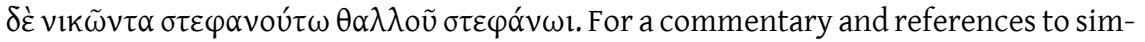
ilar epigraphical inscriptions, see Gauthier \& Hatzopoulos 1993: 75-76.

55 IK Sestos 1, 11. 30-43, 53-74. 
4. Campaign agones: Their defining characteristics are the campaign context and their non-recurrent nature: they were not intended for repetition. Hippic and gymnic competitions were common, musical performances are also documented, and even regattas could occur in the case of naval forces. The sources mainly report campaign agones during the 5th and 4th century B.C., the campaigns of Alexander the Great marking the peak period for this type of competition, at least as far as documentation goes.

The classification presented above is in no way intended to suggest a hermetical division between the individual types of agones. Naturally, there were overlaps and borderline cases: the competition in Babylon during Hephaistion's funeral mentioned above can be interpreted as a funeral contest, even though it shares some features with campaign agones; the Hermaia and Herakleia in Hellenistic gymnasia, named after the most important deities of this institution, can be seen as competitions at recurrent religious festivals as well as gymnasium agones. The classification detailed above is therefore not meant to overly systematize; instead, it should much rather serve as an reminder of the great variety of the Greek agonistic world apart from the Olympic and other cyclic competitions.

\section{BIBLIOGRAPHY}

Adams, W.L. 2007. 'The Games of Alexander the Great' in W. Heckel, L.A. Tritle \& P. Wheatley (eds.) Alexander's Empire. Formulation to Decay. Claremont, 125-38.

Angeli Bernardini, P. 2016. Il soldato e l'atleta: guerra e sport nella Grecia antica. Bologna.

Bosworth, A.B. 1995. A Historical Commentary on Arrian's History of Alexander, Vol. 2: Commentary on Books IV-V. Oxford.

Chankowski, A.S. 2004. 'L'entraînement militaire des éphèbes dans les cités grecques d'Asie mineure à l'époque hellénistique: nécessité pratique ou tradition atrophée' in J.-C. Couvenhes \& H.-L. Fernoux (eds.) 
Les cités grecques et la guerre en Asie Mineure à l'époque hellénistique. Tours, 55-76.

Crowther, N.B. 1991. 'Euexia, eutaxia, philoponia: Three Contests of the Greek Gymnasium' ZPE 85, 301-4.

Di Nanni Durante, D. 2015. Concorsi sportivi e propaganda politica in età ellenistica. Ariccia.

Ebert, J. 1972. Griechische Epigramme auf Sieger an gymnischen und hippischen Agonen. Berlin.

Ekroth, G. 2017. 'Heroes - Living or Dead?' in E. Eidinow \& J. Kindt (eds.) The Oxford Handbook of Ancient Greek Religion. Oxford, 383-96.

Gauthier, P. \& M.B. Hatzopoulos 1993. La loi gymnasiarchique de Beroia. Athens.

Golden, M. 1997. 'Equestrian Competition in Ancient Greece: Difference, Dissent, Democracy' Phoenix 51, 327-44.

Golden, M. 1998. Sport and Society in Ancient Greece. Cambridge.

Günther, L.-M. 2013. 'Alexanders III. Agone in Asia. Quellen- und interpretationskritische Überlegungen' in P. Mauritsch \& C. Ulf (eds.) Kultur(en). Formen des Alltäglichen in der Antike (Festschrift I. Weiler). Graz, 287-300.

Helmis, A. 2003. 'Entre les vivants et les morts. La fondation à la mémoire d'Aleximachos fils de Critolaous (IG XII. 7. 515; IIe siècle av. J.-C.)' in G. Thür \& F.J. Fernández Nieto (eds.) Symposion 1999. Vorträge zur griechischen und hellenistischen Rechtsgeschichte. Köln et al., 463-80.

Hornblower, S. 2008. A Commentary on Thucydides, III (Books 5.25-8.109). Oxford.

Kah, D. 2004. 'Militärische Ausbildung im hellenistischen Gymnasion' in

D. Kah \& P. Scholz (eds.) Das hellenistische Gymnasion. Berlin, 47-90.

Klee, T. 1918. Zur Geschichte der gymnischen Agone an griechischen Festen. Leipzig \& Berlin.

Kyle, D.G. 2015. Sport and Spectacle in the Ancient World. Malden².

Laum, B. 1964. Stiftungen in der griechischen und römischen Antike: ein Beitrag zur antiken Kulturgeschichte; ursprünglich in 2 Bänden. Aalen.

Lee, J.W.I. 2007. A Greek Army on the March: Soldiers and Survival in Xenophon's Anabasis. Cambridge.

Lehmann, G.A. 2015. Alexander der Große und die 'Freiheit der Hellenen'. Berlin et al. 
Mann, C. 2017. 'Losverfahren in der antiken Agonistik. Überlegungen zum Verhältnis von Religion und Sport' Gymnasium 124, 429-48.

Mann, C. 2018a. 'Könige, Poleis und Athleten in hellenistischer Zeit' Klio 100, 447-79.

Mann, C. 2018b. 'Cash and Crowns: A Network Approach to Greek Athletic Prizes' in M. Canevaro, A. Erskine, B. Gray \& J. Ober (eds.) Ancient Greek History and Contemporary Social Science. Edinburgh, 293-312.

Mann, C. forthcoming. 'Alexander the Great and Athletics' in A. Meeus \& K. Trampedach (eds.) Alexander the Great: The Legitimation of Conquest. Stuttgart.

Miller, S.G. 2004. Ancient Greek Athletics. New Haven \& London.

Moretti, L. 1975. Iscrizioni storiche ellenistiche. Vol. 2: Grecia centrale e settentrionale. Florence.

Nielsen, T.H. 2007. Olympia and the Classical Hellenic City-State Culture. Copenhagen.

Nielsen, T.H. 2015. 'The Arkadian Confederacy' in H. Beck \& P. Funke (eds.) Federalism in Greek Antiquity. Cambridge, 250-68.

Nielsen, T.H. 2016. 'Reflections on the Number of Athletic Festivals in Pre-Hellenistic Greece' in C. Mann, S. Remijsen \& S. Scharff (eds.) Athletics in the Hellenistic World. Stuttgart, 31-41.

Nielsen, T.H. 2018a. Two Studies in the History of Ancient Greek Athletics. Copenhagen.

Nielsen, T.H. 2018b. 'Athletics in Late-Archaic and Classical Arcadia' in K. Tausend (ed.) Arkadien im Altertum/Ancient Arcadia. Graz, 407-40.

Oliva, A. 1993. 'Agoni sportivi e musicali nell'Anabasi di Arriano' Nikephoros 6, 93-104.

Papakonstantinou, Z. 2002. 'Prizes in Early Greek Sport' Nikephoros 15, 5167.

Parker, R. 2004. 'New 'Panhellenic' Festivals in Hellenistic Greece' in R. Schlesier \& U. Zellmann (eds.) Mobility and Travel in the Mediterranean from Antiquity to the Middle Ages. Münster, 9-22.

Pleket, H.W. 1975. 'Games, Prizes, Athletes and Ideology. Some Aspects of the History of Sport in the Greco-Roman World' Stadion 1, 9-89.

Pleket, H.W. 2004. 'Einige Betrachtungen zum Thema 'Geld' und 'Sport” Nikephoros 17, 77-89. 
Remijsen, S. 2011. 'The So-Called 'Crown-Games': Terminology and Historical Context of the Ancient Categories for Agones' ZPE 177, 97-109. Ringwood, I.C. 1927. Agonistic Features of Local Greek Festivals, Chiefly from Inscriptional Evidence. New York.

Robert, L. 1933. 'Inscriptions grecques inédites au Musée du Louvre' RA, 121-47 (= OMS 3, 1969, 1576-1602).

Robert, L. 1984, 'Discours d'ouverture' in Actes du VIII Congrès international d'épigraphie grecque et latine, I. Athens, 35-45.

Roller, L.E. 1981a. 'Funeral Games for Historical Persons' Stadion 7, 1-18.

Roller, L.E. 1981b. 'Funeral Games in Greek Art' AJA 85, 107-19.

Schwartz, D. 2008. 2 Maccabees. Berlin.

Slater, W. 2013. 'The Victor's Return, and the Categories of Games' in P. Martzavou \& N. Papazarkadas (eds.) Epigraphical Approaches to the Postclassical Polis: Fourth Century BC to Second Century AD. Oxford, 139-63.

Weiler, I. 1975. 'War Alexander der Große wirklich ein “Sportsmann”?' in F. Thaller (ed.) Signale der Zeit (Festschrift J. Recla). Schorndorf, 271-79. Will, W. 1986. Alexander der Große. Stuttgart.

Christian Mann

Universität Mannheim

mann@uni-mannheim.de 